\title{
Introduction to Issue
}

\author{
Lewis R. Rambo ${ }^{1}$
}

Published online: 2 April 2016

(C) Springer Science+Business Media New York 2016

Welcome to this issue of Pastoral Psychology. All the articles in this issue concern conversion except one. Some fifty years ago, Earl H. Furgeson (1965) wrote the following when he was introducing a special issue of this journal:

Why should a reputable journal spend an entire issue of the subject of religious conversion? ... Wasn't that subject successfully laid to rest during the first thirty years of this century? And hasn't the revivalist movement which sustained the interest in the subject in those early years about run its course? Why bring it up again? (p. 5)

It is my hope that you, dear reader, are not skeptical about the topic of religious conversion. If you are, I can understand. Many people find the topic irrelevant, disturbing, or simply antiquated. But, conversion is important in 2016. Consider the fact that the shape of the contemporary world has been formed, in part, by massive movements of conversion that have taken place over many centuries. Why is it that most of North, Central, and South America are Christian? Why is it that most of the Middle East is Muslim? How is it possible that the largest Muslim nation in the world is Indonesia? How does one understand that virtually half of Africa is Muslim and the other half is Christian? These are just a few examples of how the map of our world has been impacted by centuries of religions shaping the world, not only geographically but also culturally. I have not even mentioned the impact of Buddhism in China, Korea, Thailand, Japan, and other countries that have long histories of this religion founded in India more than 2000 years ago.

What, you may ask, makes this relevant to Pastoral Psychology? It is becoming more and more obvious to those of us who are concerned about the human predicament (of individuals, families, communities, and the nations of the world) that religion and the dynamics of interreligious conflict over the proselytizing efforts to change people's religions are splitting families, communities, and even nations into warring factions. On the other hand, many of us know of individuals who have been transformed by their experience of conversion; they have found meaning, purpose, and forgiveness through their new faith and practice. Many people are also being empowered to overcome catastrophic loss and trauma and to find new life on the

Lewis R. Rambo

lewisrayrambo@yahoo.com

1 San Francisco Theological Seminary, San Anselmo, CA, USA 
other side of devastating addictions through religious conversion and various forms of spiritual transformation. Religious conversion is indeed relevant to Pastoral Psychology.

In this issue, the first section is devoted to essay reviews regarding the recently published Oxford Handbook of Religious Conversion. See the essays by Nathan Carlin, Alvin Dueck and Austin Johnson, and Ines Jindra and the response of the editors, Lewis Rambo and Charles Farhadian.

Pekka Lund, a professor at the University of Helsinki, Finland, reports on his ongoing research on how and why religious experiences, including conversion, are often effective in recovery from substance abuse. Central to his article is his identification of four different types of narratives that facilitate recovery from substance abuse.

Robert Montgomery, a sociologist of religion, proposes a theory of how and why Buddhism, Christianity, and Islam are the largest religions in the world. He focuses on the fact that each of these religions had an important founder - Buddha, Jesus, or Mohammed - who embodied the religion he advocated. These charismatic persons are exemplars of new ways of seeing the universe, the meaning of life, and transcendent experiences.

The last article in this issue is by Chris Schlauch, a professor at the School of Theology of Boston University. The article in this issue is part two of a series of three articles that are being published in Pastoral Psychology. His focus is on David W. Winnicott (1896-1971), one of the most important theorists on how human beings develop through the life cycle and form patterns that fundamentally shape the contours of their personality, their capacity for relationships, and their capacity for not only becoming mature human beings but also having the resources for religious experiences. Schlauch's trilogy of articles is invaluable for assessing the contributions of Winnicott to contemporary psychotherapy, religious studies, and theology.

\section{References}

Furgeson, E. H. (1965). The renewal of interest in religious conversion. Pastoral Psychology, 16(6), 5-7. 